\title{
Manajemen Pembiayaan Pendidikan Masa Pandemi Covid-19 di SMK Gazza Wiguna 1
}

\author{
Siti Waliyah"), Siti Hadiyanti Dini' ${ }^{2}$, Ahmad Syarif ${ }^{3)}$ \\ Fakultas Tarbiyah, IAI-N Laa Roiba Bogor \\ waliyahs978@gmail.com ${ }^{1)}$ \\ dinihadirachman@gmail.com ${ }^{2}$ \\ ahsyarif16@gmail.com ${ }^{3)}$
}

\begin{abstract}
This research is motivated by the Covid 19 pandemic which has changed the system in the world, especially in the education sector. The Covid 19 pandemic has greatly affected the world economy, including in Indonesia. The purpose of this study was to determine the management of education financing at Gazza Wiguna 1 Vocational High School before the Covid 19 pandemic and during the Covid 19 pandemic and to determine the impact of the pandemic on the financing at Gazza Wiguna Vocational High School 1. This study used a qualitative descriptive approach by examining the facts that occurred. . The research was conducted at SMK Gazza Wiguna 1 Kab. Bogor. The data collection technique used was the interview that came from the head of SMK Gazza Wiguna 1, the Deputy Head of the School, the treasurer of SMK Gazza Wiguna 1 and the parents of the students. Funding management at SMK Gazza Wiguna includes planning, management, implementation and supervision, focusing on the needs of schools, teachers and students. The Covid 19 pandemic has an impact on the management of education financing at the Gazza Wiguna 1 Vocational High School, namely on hiring teachers. Where during normal conditions, SMK Gazza Wiguna 1 relies on tuition fees to honor teachers, while during the Covid 19 pandemic, many students had difficulty paying tuition fees so that Gazza Wiguna 1 Vocational School made a budget rotation so that they could continue to honor teachers.
\end{abstract}

Keywords: Management, Education Financing, Covid Pandemic 19

\begin{abstract}
Abstrak
Penelitian ini dilatarbelakangi oleh pandemi Covid 19 yang telah merubah tatanan sistem di dunia khususnya di sektor pendidikan. Pandemi Covid 19 sangat memengaruhi ekonomi dunia termasuk di Indonesia. Tujuan penelitian ini adalah untuk mengetahui manajemen pembiayaan pendidikan di SMK Gazza Wiguna 1 sebelum pandemi Covid 19 dan di saat pandemi Covid 19 serta untuk mengetahui dampak pandemic terhadap pembiayaan di SMK Gazza Wiguna 1. Penelitian ini menggunakan pendekatan deskriptif kualitatif dengan mengkaji fakta-fakta yang terjadi. Penelitian dilakukan di SMK Gazza Wiguna 1 Kab. Bogor .Teknik pengumpulan data yang digunakan adalah wawancara yang bersumber dari kepala SMK Gazza Wiguna 1, Wakil Kepala Sekolah, Bendahara SMK Gazza Wiguna 1 dan orangtua siswa. Manajemen pembiayaan di SMK Gazza Wiguna meliputi perencanaan, pengelolaan, pelaksanaan dan pengawasan, berfokus kepada kebutuhan sekolah, guru dan siswa. Pandemic Covid 19 memberikan dampak terhadap manajemen pembiayaan pendidikan di SMK Gazza Wiguna 1, yaitu terhadap penghonoran guru. Dimana saat keadaan normal SMK Gazza Wiguna 1 mengandalkan iuran SPP untuk menghonor guru, sedangkan di saat pandemi Covid 19 ini banyak siswa yang kesulitan untuk membayar SPP sehingga SMK Gazza Wiguna 1 melakukan perputaran anggaran agar bisa tetap untuk menghonor guru.
\end{abstract}

Kata kunci : Manajemen, Pembiayaan Pendidikan, Pandemi Covid 19

PENDAHULUAN

Lembaga pendidikan sebagai

sebuah organisasi memiliki fungsi

ganda keluar dan ke dalam. Fungsi keluar sebagai lembaga pelayanan pendidikan berfungsi memberikan bekal berbagai kemampuan bagi peserta didik secara kognitif, afektif, dan psikomotor. 
Kedalam lembaga pendidikan berfungsi mengelola berbagai sumberdaya yang dimilikinya untuk bertahan dan berkembangnya lembaga itu menjalankan misinya (Setiowati, 2007). Seperti makna dari pendidikan yang tercantum dalam UU RI No. 20 Tahun 2003 disebutkan bahwa pendidikan adalah usaha sadar dan terencana untuk mewujudkan suasana belajar dan proses pembelajaran agar peserta didik secara aktif mengembangkan potensi dirinya untuk memiliki kekuatan spiritual keagamaan, pengendalian diri, kepribadian, kecerdasan, akhlak mulia, serta ketrampilan yang diperlukan dirinya, masyarakat bangsa dan negara. Pendidikan nasional memiliki visi terwujudnya sistem pendidikan sebagai pranata sosial yang kuat dan berwibawa untuk memperdayakan semua warga negara berkembang menjadi manusia yang berkualitas sehingga mampu dan proaktif menjawab tantangan zaman yang berubah.

$$
\text { Pendidikan merupakan salah }
$$
satu aspek terpenting dalam meningkatkan suatu pembangunan Negara. Namun, masih terdapat beberapa masalah terkait dengan penyelenggaraan pendidikan yaitu dalam hal pemerataan, relevansi, efisiensi, dan mutu pendidikan (Kurniady, 2016). Permasalahan klasik yang masih kerap menghinggapi lembaga-lembaga pendidikan, khususnya lembaga pendidikan Islam di negeri ini, adalah problem pemerataan pendidikan serta pembiayaan pendidikan yang dikatakan belum maksimal dalam realisasinya. Hal tersebut berimbas pada hampir semua komponen pendidikan lainnya. Padahal biaya pendidikan merupakan salah satu komponen masukan instrumental (instrumental input) yang sangatpenting dalam penyelenggaraan pendidikan di sekolah maupun madrasah. Dalam segala upaya pencapaian tujuan pendidikan, biaya dan pembiayaan pendidikan memiliki peranan yang sangat menentukan. Hampir tidak ada upaya pendidikan yang dapat mengabaikan peranan biaya, sehingga dapat dikatakan bahwa tanpa biaya, proses pendidikan belum bisa berjalan secara maksimal (Munir, 2013).

Salah satu elemen penting dalam mutu pendidikan adalah pembiayaan. Pembiayaan kadang juga merupakan inti dari setiap permasalahan pendidikan, apalagi jika dihubungkan dengan Pembiayaan pendidikan pada swasta yang seluruhnya bersumber dari 
dana masyarakat walaupun sebenarnya ada bantuan dari pemerintah tetapi tidak terlalu signifikan untuk dibuat acuan dalam penentuan kebijakan maka kualitas pendidikan tinggi swasta tentu sangat bergantung pada bagaimana manajemen pembiayaannya. Manajemen Pembiayaan yang baik merupakan salah satu kunci dari keberhasilan sebuah lembaga pendidikan untuk memajukan atau meningkat kualitasnya (Abidin \& Achmad Anwar, 2017).

Menurut UU No. 20 Tahun 2003 pasal 35 tentang Standar Nasional Pendidikan, disebutkan bahwa standar nasional pendidikan digunakan sebagai acuan pengembangan kurikulum, tenaga kependidikan, sarana dan prasarana, pengelolaan dan pembiayaan. Melalui perencanaan strategik di bidang pendidikan, lembaga pendidikan mampu menyiapkan output. Hoy \& Miskel (2008) banyak faktor yang mempengaruhi mutu sekolah diantaranya budaya organisasi, kepemimpinan kepala sekolah, iklim organisasi,sarana-prasarana, kinerja guru, dan pembiayaan. Morphet, (1983), "biaya pendidikan memberikan pengaruh yang positif melalui faktor kepemimpinan dan manajemen pendidikan dan tenaga pendidik yang kompeten dalam meningkatkan pelayanan pendidikan melalui peningkatan mutu."

$$
\text { Pembukuan di SMK Gazza }
$$

Wiguna dalam pelaksanaan pembiayaannya menggunakan kartu SPP yang dipegang oleh siswa dan buku kas umum lalu di input ke komputer untuk dijadikan laporan bulanan, laporan per 6 bulan dan laporan tahunan kepada sekolah dan yayasan. Kendala atau dampak dari pandemi Covid 19 terhadap pembiayaan di SMK Gazza Wiguna berdampak pada anggaran untuk menghonor guru.

Dilansir dari artikel online Halodoc.com yang diakses pada tanggal 24 Agustus 2020 Coronavirus merupakan keluarga besar virus yang menyebabkan infeksi saluran pernapasan atas ringan hingga sedang, seperti penyakit flu. Banyak orang terinfeksi virus ini, setidaknya satu kali dalam hidupnya. Namun, beberapa jenis virus corona juga bisa menimbulkan penyakit yang lebih serius, seperti: Middle East Respiratory Syndrome (MERS-CoV), Severe Acute Respiratory Syndrome (SARS-CoV), Pneumonia. 
SARS yang muncul pada November 2002 di Tiongkok, menyebar ke beberapa negara lain. Mulai dari Hongkong, Vietnam, Singapura, Indonesia, Malaysia, Inggris, Italia, Swedia, Swiss, Rusia, hingga Amerika Serikat. Epidemi SARS yang berakhir hingga pertengahan 2003 itu menjangkiti 8.098 orang di berbagai negara. Setidaknya 774 orang mesti kehilangan nyawa akibat penyakit infeksi saluran pernapasan berat tersebut.

COVID-19 atau dikenal juga dengan Novel Coronavirus (menyebabkan wabah pneumonia di kota Wuhan, Tiongkok pada Desember 2019, dan menyebar ke negara lainnya mulai Januari 2020. Indonesia sendiri mengumumkan adanya kasus covid 19 dari Maret 2020 (Rizal, 2020)

Pandemi Covid-19 memaksa kebijakan social distancing, atau di Indonesia lebih dikenalkan sebagai physical distancing (menjaga jarak fisik) untuk meminimalisir persebaran Covid-19. Kebijakan ini diupayakan untuk memperlambat laju persebaran virus Corona di tengah masyarakat. Kementrian Pendidikan dan Kebudayaan (Kemdikbud) merespon dengan kebijakan belajar dari rumah, melalui pembelajaran daring (Ashadi, 2020). Dengan adanya kebijakan pembelajaran dari rumah atau daring maka segala kegiatatan di luar belajar seperti kegiatan ekstrakulikuler, outing classs ditiadakan untuk sementara.

Pandemi Covid-19 telah membunuh berbagai sektor produk, bisnis, industri, hingga kebiasaan manusia. Managing Partner Inventure Yuswohady mengatakan, setidaknya ada lima alasan Covid-19 bisa membunuh berbagai hal, yaitu kill contact, kill crowd, kill mobility, kill leisure, dan kill economy. "Jadi ketika contact, crowd, mobility, leisure, semuanya dilakukan pembatasan, tidak ada pergerakan uang, barang, ataupun manusia, maka akhirnya ekonomi dibunuh juga oleh Covid-19 ini," ujarnya (Oktiani, 2020).

Tujuan dari penelitian ini adalah 1) Untuk mengetahui manajemen pembiayaan pendidikan di SMK Gazza Wiguna 1 sebelum pandemic. 2) Untuk mengetahui manajemen pembiayaan pendidikan di SMK Gazza Wiguna 1 di masa pandemi. 3) Untuk mengetahui dampak pandemic terhadap pembiayaan di SMK Gazza Wiguna 1 


\section{KAJIAN TEORI}

Dalam kamus Webster disebutkan

bahwa

pengelolaan/manajemen berasal dari kata manage (maneggio, Italia), berarti mengurus, memimpin, mencapai, dan memerintah. Kata ini mendapat pengaruh dari bahasa Prancis, yaitu manège yang berarti kepemilikan kuda (dan dalam bahasa Inggris yang berarti seni mengendalikan kuda). Bahasa Prancis mengadopsi kata ini dari bahasa Inggris menjadi ménagement, yang artinya seni melaksanakan dan mengatur. Pengelolaan atau manajemen berasal dari kata to manage yang artinya mengatur. Pengaturan dilakukan melalui proses dan diatur berdasarkan urutan dari fungsi-fungsi manajemen itu. Dengan demikian, manajemen merupakan suatu proses untuk mewujudkan tujuan yang diinginkan ( daam A. Rusdiana, 2014).

Dalam sudut pandang islam manajemen diistilahkan dengan menggunakan kaka Al-Tadbir (pengaturan). Kata ini merupakan derivasi dari kata dabbara (mengatur) yang banyak terdapat dalam alquran seperti firman Allah SWT

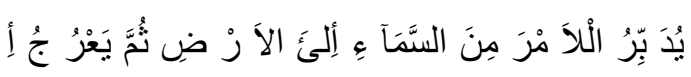

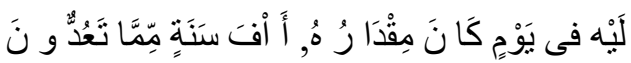

Artinya:

"Dia mengatur urusan dari langit ke bumi, Kemudian (urusan) itu naik kepadanya dalam satu hari yang kadarnya adalah seribu tahun menurut perhitunganmu”. (QS.As-Sajdah 7)

Dari isi kandungan ayat di atas dapatlah kita ketahui bahwa Allah SWT adalah pengatur alam ( $A l$ Mudabbir/Manager). Keteraturan alam raya ini merupakan bukti kebesaran Allah SWT dalam mengelola alam ini. Namun, karena manusia yang diciptakan Allah SWT telah dijadikan sebagai khalifah bumi, maka manusia harus mengatur dan mengelola bumi dengan sebaik-baiknya sebagaimana Allah mengatur alam raya ini (Munir, 2013).

Pengertian manajemen didefinisikan dalam berbagai cara, tergantung dari sudut pandang, keyakinan serta pengertian dari pembuat definisi. Secara umum pengertian manajemen adalah pengelolaan suatu pekerjaan untuk memperoleh hasil dalam rangka pencapaian tujuan yang telah ditentukan dengan cara menggerakan orang-orang lain untuk bekerja. Pengelolaan pekerja itu terdiri 
dari berbagai macam ragam, pada pasal 2 (1) Pendanaan pendidikan pendidikan, pelayanan sosial, olahraga, menjadi tanggung jawab bersama antara kesehatan, keilmuan dan lain-lain. Bahkan hampir setiap aspek kehidupan manusia memerlukan pengelolaan oleh karena itu, manajemen ada dalam setiap aspek kehidupan manusia dimana terbentuk suatu kerja sama (organisasi). (Herujito, 2011).

Investasi dalam bidang pendidikan memiliki banyak fungsi selain fungsi teknis ekonomis yaitu fungsi sosial kemanusiaan, fungsi politis, fungsi budaya dan fungsi kependidikan. Dalam fungsi teknis ekonomis, pendidikan dikaitkan dengan pertumbuhan ekonomi (teori modal manusia). Orang yang memiliki tingkat pendidikan lebih tinggi, diukur dengan lamanya waktu untuk sekolah akan memiliki pekerjaan dan upah yang lebih baik dibandingkan dengan orang yang pendidikannya lebih rendah. Apabila upah mencerminkan produktivitas, maka semakin banyak orang yang memiliki pendidikan tinggi, semakin tinggi produktivitas dan hasil ekonomi nasionalnya akan tumbuh lebih tinggi (Atmanti Dwi, H, 2005).

Dalam Peraturan Pemerintah Republik Indonesia Nomor 48 Tahun 2008 Tentang Pendanaan Pendidikan Pemerintah, pemerintah daerah, dan masyarakat. Pasal 3 (1) Biaya pendidikan meliputi: a. biaya satuan pendidikan (Risnandi \& Prayog, 2019). Adapun besarnya biaya pendidikan yang dibebankan pada pemerintah sesuai amanat Pasal 31 ayat (4) Undang-Undang Dasar Negara Republik Indonesia Tahun 1945 yang telah diamandemen adalah sebesar $20 \%$ dari Anggaran pendapatan dan belanja Negara pada masa tahun anggaran berjalan dan kebijakan 20\% ini tidak dalam lingkup nasional semata tetapi juga dari anggaran APBD untuk propinsi dan pemerintah daerah kabupaten/kota untuk pendidikan dasar baik jalur sekolah maupun non sekolah sesuai PP nomor 48 tahun 2008 tentang pendanaan pendidikan (Abidin \& Achmad M, 2017). Peraturan Menteri Pendidikan Nasional Nomor 69 Tahun 2009 Tentang Standar Biaya Operasi Nonpersonalia Tahun 2009 Untuk Sekolah Dasar/Madrasah Ibtidaiyah (SD/MI), Sekolah Menengah Pertama/Madrasah Tsanawiyah (SMP/MTS), Sekolah Menengah Atas/Madrasah Aliyah. (Risnandi \& Prayogo, 2019) 
Beberapa istilah yang sering digunakan dalam pembiayaan sekolah, yakni school revenues, school expenditures, capital dan current cost. Dalam pembiayaan sekolah tidak ada pendekatan tunggal dan yang paling baik untuk pembiayaan semua sekolah karena kondisi tiap sekolah berbeda. Setiap kebijakan dalam pembiayaan sekolah akan mempengaruhi bagaimana sumber daya diperoleh dan dialokasikan. (Fattah N, 2008)

Pembiayaan dalam dimensi ilmu administrasi pendidikan dikenal ada tujuh dimensi, yaitu : 1. Konteks sosiologis dan budaya dalam manajemen pendidikan, 2. Proses belajar mengajar, 3. Ekonomi dan pembiayaan pendidikan, 4. Studi dan teori organisasi, 5. Kepemimpinan dan kemanagemenan, 6. Kebijakan dan politik dalam manajemen pendidikan, 7 . Legal dan etik dalam manajemen pendidikan (Setiowati E.N, 2007).

Di dalam terminologi administrasi keuangan, khususnya adminsitrasi keuangan bidang pendidikan, dibedakan antara biaya (cost) dan pembelanjaan (expenditure). Biaya (cost) adalah nilai besar dana yang diperkirakan perlu disediakan untuk membiayai kegiatan tertentu, misalnya kegiatan akademik, kegiatan kesiswaan, dan sebagainya. Sedangkan pembelanjaan (expenditure) adalah besar dana riil yang dikeluarkan untuk membiayai unit kegiatan tertentu, misalnya kegiatan praktikum siswa. Oleh karena itu, seringkali muncul adanya perbedaan antara biaya yang dianggarkan dengan pembelanjaan riil (Mufid S, 2012). Biaya (cost) dapat diartikan pengeluaran yang dalam istilah ekonomi biaya/pengeluaran dapat berupa uang atau bentuk moneter lainnya. Biaya pendidikan merupakan hal yang penting dalam penyelenggaraan pendidikan. Dapat dikatakan bahwa proses pendidikan tidak dapat berjalan tanpa dukungan biaya. Biaya pendidikan merupakan salah satu komponen masukan instrumental (instrumental input) yang sangat penting dalam penyelenggaraan pendidikan, khususnya di sekolah. Berdasarkan sumbernya, biaya pendidikan dapat digolongkan menjadi empat jenis: pertama, biaya pendidikan yang dikeluarkan oleh pemerintah. Kedua, biaya pendidikan yang dikeluarkan oleh masyarakat atau orang tua/wali siswa. Ketiga, biaya pendidikan yang dikeluarkan oleh masyarakat bukan orang tua siswa, misalnya 
sponsor dari lembaga keuangan dan perusahaan. Dan keempat, dari lembaga pendidikan itu sendiri (Harsono, 2007).

Masing-masing sumber tersebut adalah pos strategis dalam sirkulasi pembiayaan pendidikan untuk menopang program pendidikan yang diagendakan, baik oleh pihak lembaga pendidikan sendiri sebagai wadah pemberdayaan dan pengembangan, maupun pemerintah sebagai pihak yang mempunyai kebijakan dalam penganggaran yang secara institusional memiliki tanggung jawab utama dan pendorong ke arah efektivitas dan efisensi aktivitas pendidikan. Oleh karena demikan, faktor biaya adalah sangat berpengaruh terhadap penyelenggaraan pendidikan (Munir A, 2013).

Saat ini, penerapan pembiayaan pendidikan belum dapat sepenuhnya mencerminkan keberpihakan kepada peserta didik dari kalangan kurang beruntung dari segi ekonomi. Ke depan, diharapkan sistem pembiayaan pendidikan dapat mencerminkan ketercapaian mutu pendidikan. Menyikapi tuntutan masyarakat dewasa ini terhadap mutu pendidikan yang tinggi, maka perlu mengadopsi sistem pembiayaan subsidi silang di mana dalam sistem tersebut diprioritaskan untuk siswa yang tidak memiliki akses kepada pendidikan karena secara ekonomi kurang mampu. Ini tercermin dalam Pasal 52 huruf f, Peraturan Pemerintah Republik Indonesia Nomor 48 Tahun 2008 tentang Pendanaan Pendidikan di mana salah satu ketentuannya menetapkan bahwa dana pendidikan satuan pendidikan yang diselenggarakan oleh Pemerintah Pusat maupun Pemerintah daerah menerapkan sistem subsidi silang yang diatur tersendiri oleh satuan pendidikan (Depdiknas, 2008).

Pembiayaan pendidikan yang efektif dan efisien merupakan tanggung jawab bersama, baik Pemerintah maupun masyarakat. Perlu dibangun rasa saling percaya, baik antara Pemerintah dengan masyarakat dan masyarakat dengan masyarakat itu sendiri dapat ditumbuhkan. Keterbukaan, partisipasi, akuntabilitas dalam penyelenggaraan pendidikan mulai dari perencanaan, pelaksanaan dan pengawasan menjadi kata kunci untuk mewujudkan efektivitas pembiayaan pendidikan. Biaya pendidikan di Indonesia saat ini tidak murah lagi jika dilihat dari penghasilan 
rakyat Indonesia setiap harinya. Masalah mahalnya biaya pendidikan tidak hanya pendidikan di perguruan tinggi, melainkan juga biaya pendidikan di sekolah dasar sampai sekolah menengah ke atas walaupun sekarang ini sekolah sudah mendapat bantuan operasional sekolah (BOS). Namun semuanya masih belum mencukupi biaya pendidikan bagi masyarakat yang kurang mampu. Pembiayaan pendidikan terdiri atas biaya investasi, biaya operasi, dan biaya personal. Biaya investasi satuan pendidikan meliputi biaya penyediaan sarana dan prasarana, pengembangan sumber daya manusia, dan modal kerja tetap. Biaya personal meliputi biaya pendidikan yang harus dikeluarkan oleh peserta didik untuk bisa mengikuti proses pembelajaran. Biaya operasi satuan pendidikan meliputi gaji pendidik dan tenaga kependidikan serta segala tunjangan yang melekat pada gaji, bahan atau peralatan pendidikan habis pakai dan biaya operasi pendidikan tak langsung berupa daya, air, jasa telekomunikasi, pemeliharaan sarana dan prasarana, uang lembur, transportasi, konsumsi, pajak, asuransi, dan lain sebagainya. Kompleksitas biaya yang timbul berdasarkan uraian di atas merupakan suatu proses yang secara bersamasama harus ditelaah, diselesaikan, dan diharapkan dapat menghasilkan suatu model pembiayaan pendidikan yang terbaik sebagai upaya dalam mewujudkan cita-cita pendidikan nasional menuju masyarakat yang adil dan makmur (Ferdi, 2013).

\section{METODOLOGI PENELITIAN}

Penelitian ini menggunakan pendekatan deskriptif kualitatif dengan mengkaji fakta-fakta yang terjadi. Penelitian dilakukan di Kecamatan Cisarua, Kelurahan Cipayung Girang, RT.01 RW.03 dari 13 Agustus sampai Agustus 2020.

Metode kualitatif deskriptif ini digunakan untuk menggambarkan proses manajemen pembiayaan pendidikan di SMK Gazza Wiguna 1 Kab. Bogor sebelum pandemi Covid 19 dan pada saat pandemi Covid 19, yang terdiri atas proses penganggaran, proses pencatatan keuangan, proses pengawasan keuangan, dan proses pertanggungjawaban keuangan.

Teknik pengumpulan data yang digunakan adalah wawancara yang bersumber dari kepala SMK Gazza Wiguna 1, Wakil Kepala Sekolah, Bendahara SMK Gazza Wiguna 1 dan 
orangtua siswa. Observasi terkait dengan manajemen pembiayaan, dan dokumentasi terkait dengan pencatatan keuangan di SMK Gazza Wiguna 1 Kab. Bogor.

\section{HASIL DAN PEMBAHASAN}

Perencanaan Pembiayaan

Setiap kegiatan manajemen selalu dimulai dengan proses perencanaan, begitu juga kegiatan manajemen pembiayaan pendidikan di SMK Gazza Wiguna 1 yang melakukan perencanaan pembiayaan pendidikan di setiap awal tahun ajaran. Perencanaan pembiayaan sekolah mengadakan rapat berkaitan dengan kebutuhan selama satu tahun pelajaran dalam bentuk RKAS (Rencana Kerja Anggaran Sekolah ) dibuat di awal tahun pelajaran dengan yayasan, kepala sekolah dan struktural. Perencanaan meliputi kebutuhan sekolah dan kegiatan sekolah. Jika terdapat pengeluaran yang lebih besar dibandingkan pemasukan, maka biaya yang di anggarkan di RKAS akan diadakan pengurangan. Pada saat pelaksanaan dibutuhkan keahlian seorang kepala sekolah dalam memanaj anggaran tersebut (Kepala Sekolah SMK Gazza Wiguna 1, 2020).
Perencanaan pada dasarnya merupakan suatu proses untuk menetapkan di awal berbagai hasil akhir yang ingin dicapai oleh instansi atau organisasi di masa mendatang (Solihin, 2012).Dalam strategi pembiayaan, kegiatan penentuan kebutuhan pembiayaan merupakan langkah pertama yang harus dilakukan oleh madrasah. Keputusan itu menyangkut pengadaan, penggunaan, pemeliharaan dan penghapusan pembiayaan dibuat dalam sebuah kerangka perencanaan pelayanan dan finansial yang terintegrasi dalam konteks kebijakan madrasah sebagai acuan prioritas alokasi pembiayaan madrasah (Rusdiana, 2017).

Beberapa pendapat terkait dengan perencanaan pendidikan, antara lain Coombs (1982) menyatakan bahwa perencanaan pendidikan suatu penerapan yang rasional dianalisis sistematis proses perkembangan pendidikan dengan tujuan agar pendidikan itu lebih efektif dan efisien serta sesuai dengan kebutuhan dan tujuan peserta didik dan masyarakat. Sementara itu, Enoch menyatakan bahwa perencanaan pendidikan merupakan suatu proses mempersiapkan seperangkat keputusan 
untuk kegiatankegiatan di masa depan yang di arahkan untuk mencapai tujuantujuan dengan cara-cara optimal untuk pembangunan ekonomi dan sosial secara menyeluruh dari suatu Negara.

Perencanaan merupakan hal yang penting untuk memulai kegiatan dalam mewujudkan tujuan dari sebuah organisasi agar semua hal bisa berjalan sistematis dan jelas. Bendahara SMK Gazza Wiguna mengatakan bahwa proses perencanaan pembiayaan di sekolah dilakukan oleh kepala sekolah yang kemudian akan disetujui oleh yayasan, perencanaan ini meliputi tujuan jangka pendek, menengah dan panjang. Disaat pandemic covid 19 seperti ini banyak program yang tertundah sehingga khususnya di semester genap tahun ajaran 2020/2021 banyak kegiatan yang tidak terlaksana.

Menurut Garner (2004) merumuskan sikuensi perencanaan pembiayaan yang strategis sebagai berikut: 1) misi (mission), 2) tujuan jangka panjang (goals), 3) tujuan jangka pendek (objectives), 4) program, layanan, aktivitas (programs, services, activities), tujuan jangka panjang, tujuan jangka pendek berdasarkan kondisi riil unit sekolah (site-based unit goals \& objectives), 5) target: baik outcomes maupun outputs, 6) anggaran (budget), dan 7) perencanaan pembiayaan yang strategis (strategic financial plan).

Didalam tujuan atau sasaran dari perencanaan sekolah sendiri kembali lagi untuk kegiatan siswa, kesejahteraan guru dan untuk sarana prasarana. Ada juga dana sumbangan kesehatan yang dibayar 25.000 pertahun oleh siswa seperti jika ada orangtua siswa yang meninggal maka dana sumbangan ini nanti yang akan disumbangkan, dan juga terdapat iuran OSIS sebesar 75.000 pertahun untuk anggaran kegiatan OSIS seperti kegiatan ekstrakulikuler dan kelas duanya ada biaya PSG (Praktek Sistem Ganda) untuk praktek diluar untuk kebutuhan mereka (Bendahara SMK Gazza Wiguna)

Perencanaan menghimpun sejumlah sumber daya yang diarahkan untuk mencapai suatu tujuan berhubungan dengan anggaran sebagai penjabaran suatu rencana ke dalam bentuk dana untuk setiap komponen kegiatan. Dalam pembiayaan pendidikan ada beberapa aspek penting yang harus dipahami yaitu konsep penganggaran pendidikan, pengklasifikasian kegiatan, penentuan prioritas kebijakan, penentuan 
standarisasi, penentuan biaya satuan dalam penganggran biaya pendidikan. Ada beberapa mekanisme penganggaran yaitu mekanisme penganggaran rutin untuk membiayai kegiatan pendidikan yang bersifat rutin (berulang dalam jangka waktu kurang dari setahun) dan mekanisme penganggran untuk membiayai kegiatan-kegiatan pendidikan yang bersifat investasi (Matin,2014).

(Fattah, 2002 ) menjelaskan budget merupakan rencana operasional yang dinyatakan secara kuantitatif dalam bentuk satuan uang yang digunakan sebagai pedomandalam melaksanakan kegiatan lembaga dalam kurun waktu tertentu. Anggaran mempunyai tiga manfaat yaitu; (1) sebagai alat penaksir; (2) sebagai alat otorisasi pengeluaran dana; dan (3) sebagai alat efisiensi. Penyususnan anggaran harus didasarkan pada prinsipprinsip antara lain : (1) adanya pembagian wewenang dan tanggung jawab yang jelas dalam sistem menejemen dan organisasi; (2) adanya sistem akuntasi yang memadai dalam melaksanakan anggaran; (3) adanya penelitian dan analisis untuk menilai kinerja organisasi; dan (4) adanya dukungan dari pelaksana mulai dari tingkat atas sampai tingkat paling bawah. Prosedur penyusunan anggaran yaitu: (1) mengidentifikasi kegiatankegiatan yang akan dilakukan selama periode anggaran; (2) mengidentifikasi sumber-sumber yang dinyatakan dalam uang, jasa dan barang; (3) semua sumber dinyatakan dalam bentuk uang karena anggaran pada dasarknya merupakan penyataan financial; (4) memformulasikan anggaran dalam bentuk format yang telah disetujui dan dipergunakan oleh instansi tertentu; (5) menyusun usulan anggaran untuk memperoleh persetujuan dari pihak berwenang; (6) melakukan revisi anggaran; (7) persetujuan revisi anggran; (8) pengesahan anggaran.

(Sagala,2011) menyebutkan: -Budget (rencana) adalah (1) rencana operasional keuangan mencakup estimasi tentang pengeluaran untu suatu periode tertentu/kurun waktu; (2) rencana sistematik untuk efisiensi pemanfaatan tenaga, industri (sumber); dan (3) rencana keuangan yang diprioritaskan dengan pola pengawasan operasinal pada masa datang suatu lembaga".

\section{Pengelolaan Pembiayaan}

Pengelolaan pembiayaan pendidikan mempunyai manfaat yang 
cukup besar bagi kelangsungan pembelajaran di sekolah. Pengelolaan pembiayaan pendidikan bersumber dari partisipasi masyarakat untuk meningkatkan jalannya roda pendidikan, tanpa partisipasi masyarakat, maka pendidikan tidak akan berjalan dengan baik"(Muhajirin, 2012) Di SMK Gazza Wiguna 1 pedoman pengelolaan untuk dana partisipasi dari masyarakat meliputi lingkup structural yayasan dan kepala sekolah. Jika dari dana BOS pedomannya dari Kemendikbud.

(Undang-undang tentang Sistem Pendidikan Nasional No. 20, 2003) pasal 48 menyatakan bahwa pengelolaan dana pendidikan berdasarkan pada prinsip transparansi (keterbukaan sumber keuangan,jumlah, rincian penggunaan, pertanggungjawaban, dsb), akuntabilitas (dapat dipertanggung jawabkan sesuai dengan perencanaan yang telah ditetapkan), efektivitas (kualitas outcome sesuai rencana), dan efesiensi (kuantitas hasil sangat bagus perbandingan yang terbaik antara masukan/input (pikiran, waktu, dan biaya) dan keluaran/output/hasil).

Fokus manajemen keuangan dan pembiayaan pendidikan bersifat publik, menurut Abdullah $(2012 ; 12)$ merupakan upaya pengelolaan sumber dana yang tersedia di lembaga

pendidikan untuk dapat dipergunakan seefektif mungkin, dalam pengertian bahwa dana

(uang) yang tersedia itu bisa dipergunakan untuk memberikan layanan pendidikan sesuai dengan perencanaan (budgeting) yang sudah ditetapkan. Prinsip-prinsip dalam manajemen keuangan dan pembiayaan lembaga pendidikan di Indonesia di atur dalam Undang- undang Nomor 20 Tahun 2003 tentang Sistem Pendidikan Nasional, pasal 48 menyatakan bahwa pengelolaan dana pendidikan berdasarkan pada prinsip keadilan, efisiensi, transparansi, dan akuntabilitas publik.

\section{Pelaksanaan Pembiayaan}

Pelaksanaan adalah suatu tindakan atau pelaksanaan dari sebuah rencana yang sudah disusun secara matang dan terperici, implementasi biasanya dilakukan setelah perencanaan sudah dianggap siap. Secara sederahana pelaksanaan bisa diartikan sebagai penerapan (Usaman, 2002) Di Indonesia peraturan pelaksanaan pembiayaan pendidikan diatur dalam Peraturan Pemerintah (PP) No.19 tahun 2005 dan 
PP No.48 tahun 2008 (Depdiknas, 2008). Kedua PP tersebut pada umumnya membicarakan pembiayaan pendidikan yang terdiri atas; biaya investasi, biaya operasional dan biaya personal. Walaupun pada PP No.48 tahun 2008 penyebutannya berbeda tetapi pada intinya sesuai dengan pembiayaan yang terdapat dalam PP No.19 tahun 2005. Biaya investasi dan biaya operasional inilah yang dimaksudkan sebagai unit cost pendidikan dalam PP No.19 tahun 2005. Menurut Kepala Sekolah SMK Gazza Wiguna 1 Pelaksanaan pembiayaan jika terdapat ketidak seimbangan antara pemasukan dan pengeluaran maka anggaran untuk pengeluaran akan dikurangi biayanya. Disaat pandemic Covid 19 ini pelaksanaan pembiayaan focus untuk penghonoran guru dan peremajaan sekolah seperti mengecat ulang dan merawat gedung sekolah. Biaya pemeliharaan dan perbaikan ringan adalah biaya untuk memelihara dan memperbaiki sarana dan prasarana sekolah/madrasah untuk mempertahankan kualitas sarana dan prasarana sekolah/madrasah agar layak digunakan sebagai tempat belajar dan mengajar ( Kemendikbud, 2009)
Dalam

melaksanakan pembiayaan yang ada di SMK Gazza Wiguna 1 jenis pembiayaan berupa biaya langsung yang digunakan untuk membiayai pengeluaran rutin dan non rutin sekolah. Sedangkan sumber pembiayaan sekolah dari dana BOS dan siswa.

Biaya langsung merupakan biaya penyelenggaraan pendidikan yang dikeluarkan oleh sekolah, siswa atau keluarga siswa, biaya langsung ini lebih mudah dihitung karena diketahui oleh para wajib pajak dan data di sekolah tersedia, sementara biaya tidak langsung sulit untuk dihitung. Biaya langsung berwujud dalam bentuk pengeluaran uang yang secara langsung digunakan untuk membiayai penyelengaraan proses belajar mengajar. Biaya langsung berpengaruh terhadap kualitas output pendidikan dan penyelenggaraan kegiatan-kegiatan akademik lainya (Suhardan, 2012).

\section{Pengawasan Pembiayaan}

Menurut Kepala Sekolah dalam pelaksanaan pengawasan pembiayaan di SMK Gazza Wiguna 1 Prosedur pengawasan dari partisipasi masyarakat maka komite terlibat,untuk yayasan, sekolah harus tetap melaporkan hasil dari setiap kegiatan tersebut kepada 
yayasan sebagai bentuk pengawasan, kalo untuk dana BOS pengawasannya harus di laporkan ke Provinsi dalam bentuk laporan online dan laporan fisik.

(Fattah,2002), pengawasan anggaran bertujuan untuk mengukur, membandingkan, menilai alokasi biaya dan tingkat penggunaannya. Pengawasan anggaran diharapkan dapat mengetahui sampai dimana tingkat efektivitas dan efisiensi dari penggunaan sumber-sumber dana yang tersedia. Pengawasan anggaran dilaksanakan untuk mengetahui tingkat kesesuaian antara biaya yang dialokasikan untuk setiap komponen dalam anggaran dengan realisasi anggaran.

Untuk dapat tercapai tujuan pendidikan yang optimal, salah satu hal paling penting, yaitu mengelola biaya dengan baik sesuai dengan kebutuhan dana yang diperlukan. Administrasi pembiayaan minimal mencakup perencanaan, pelaksanaan, dan pengawasan. Penyaluran anggaran perlu dilakukan secara strategis dan integratif antara pemangku kepentingan (stakeholder) untuk mewujudkan kondisi ini, perlu dibangun rasa saling percaya, baik internal Pemerintah maupun antara Pemerintah dengan masyarakat dan masyarakat dengan masyarakat itu sendiri dapat ditumbuhkan. Keterbukaan, partisipasi, dan akuntabilitas dalam penyelenggaraan pendidikan mulai dari perencanaan, pelaksanaan, dan pengawasan menjadi kata kata kunci untuk mewujudkan efektivitas pembiayaan pendidikan (Ferdi W.P, 2013).

Pelaporan pembiayaan SMK Gazza Wiguna 1 dalam bentuk pembukuan seperti buku kas umum dan kas tunai sebagai bukti. Untuk pembukuannya ada kartu SPP dan buku kas umum lalu di input ke computer untuk dijadikan laporan bulanan, laporan per 6 bulan dan laporan tahunan kepada sekolah dan yayasan.Proses pengawasan terdiri dari tiga kegiatan pokok (1) memantau (monitoring); (2) menilai; dan (3) melaporkan hasil-hasil temuan, kegiatan/monitoring dilakukan terhadap kinerja aktual, baik dalam proses maupun hasilnya. Auditing senantiasa berkaitan dengan masalah keuangan dan mengandung makna bahwa dalam prosesnya perhatian dari pemeriksaan ditikberatkan pada aliran uang yang ada dalam organisasi. Aliran uang tersebut mencakup pertanggungjawaban penerimaan, 
penyimpanan dan pembayaran atau penyerahan uang yang dilakukan oleh bendaharawan kepada pihak-pihak yang berwenang. (Arikunto.S, 2008).

Menurut Pigawahi dalam Manullang (1990, dalam Budi, 2018) menyatakan bahwa pada sekolah dasar yang efektif proses pengawasan mencakup kegiatan berikut: pemahaman tentang ketentuan pelaksanaan dan masalah yang dihadapi, menentukan obyek pengawasan, menentukan sistem, prosedur, metode dan teknik pengawasan, menentukan norma yang dapat dipedomani, menilai penyelenggaraan, menganalisis dan menentukan sebab penyimpangan, menentukan tindakan korektif dan menarik kesimpulan atau evaluasi. Selanjutnya mengukur atau mengevaluasi prestasi kerja terhadap standar yang telah ditentukan dan membetulkan penyimpangan yang terjadi. Jika ada penyimpangan dapat segera dan cepat dilakukan pembetulan. Pengawasan pembiayaan memiliki fungsi mengawasi perencanaan pembiayaan dan pelaksanaan penggunaan pembiayaan. Walaupun perencanaan yang baik telah ada, yang telah diatur dan digerakkan, belum tentu tujuan dapat tercapai, sehingga masih perlu ada pengawasan.

Pada dasarnya pengawasan merupakan usaha sadar untuk mencegah kemungkinan-kemungkinan penyimpangan pelaksanaan dari rencana yang telah ditetapkan. Apakah pelaksananya telah tepat dan telah menduduki tempat yang tepat, apakah cara bekerjanya telah betul dan aktivitasnya telah berjalan sesuai dengan pola organisasi. Kalau terdapat kesalahan dan penyimpangan, maka segera diperbaiki.

Dampak Pandemic Covid 19 Terhadap Pembiayaan Pendidikan

Pada awal kebijakan lockdown kota Wuhan dan pembatasan akses wilayah lainnya di RRC, berdampak pada berkurangnya perayaan Imlek di Tiongkok, karena penutupan akses transportasi dan kegiatan bisnis yang berdampak pada supply chain aktivitas bisnis pabrikan, perdagangan dan bahkan jasa di wilayah terdampak dan wilayah sekitar. Pada awal penyebarannya, Indeks pasar modal bisa menjadi cerminan merosotnya aktivitas ekonomi di Tiongkok (Taufik \& Ayunigtyas, 2020). Teguh Santoso (2020) menjelaskan bahwa bursa saham Shanghai Index, TWSE, dan Hangseng 
menunjukkan nilai negatif dengan indeks yang menurun masing-masing sebesar minus $7.72 \%$, minus $5,72 \%$, dan minus 2,82\%. Merosotnya indeks bursa saham Tiongkok tersebut lebih rendah dibandingkan pada saat serangan virus SARS pada 2003, yang mana Shanghai Index dan Hangseng merosot sebesar $3,4 \%$ dan $-2,58 \%$. Potensi dampak penyebaran virus corona terhadap industri perbankan pada pertumbuhan kredit, pendapatan non bunga dan non bunga bank-bank di kawasan Asia Tenggara diperkirakan bakal melambat.

Merespon pandemi Corona

Virus Disease 2019 (Covid-19), pemerintah Indonesia mulai menerapkan pembatasan dengan kebijakan social distancing (jaga jarak sosial, menghindari kerumunan), lalu physical distancing (jaga jarak antar orang minimal 1,8 meter) sejak awal Maret 2020. Kebijakan itu telah menurunkan secara drastis aktivitas dan pergerakan orang di Jabodetabek dan kota-kota besar. Hal ini dapat dilihat dari menurunnya jumlah penumpang pada berbagai sarana transportasi mulai pesawat terbang, kereta api komuter, bus dan busway, angkot, taksi, taksi online, bajaj, hingga ojek dan ojek online (ojol).
Dikatakan oleh Kepala SMK Gazza Wiguna 1 bahwa dampak dari pandemic Covid 19 sangat jelas, iuran SPP tidak seperti biasanya sedangkan honor guru haru tetap di keluarkan setiap bulannya, ini menjadi sesuatu yang benar benar harus di pikirkan oleh kepala sekolah bahkan mungkin sampai harus meminjam uang karna untuk honor harus tetap dikeluarkan.

\section{Menteri Keuangan (Menkeu)} menjelaskan Pendapatan Negara pada bulan Maret 2020 tumbuh positif. Meskipun kemudian Pemerintah waspada terhadap dampak pandemi di bulan mendatang, mengingat wabah ini baru mulai meluas di Indonesia pada minggu kedua Maret 2020. "Untuk Indonesia kita lihat sudah ada 5.516 kasus baru Covid-19 sesuai data kemarin dan masih terkonsentrasi mayoritas ada di Daerah Khusus Ibukota (DKI) Jakarta. Ini yang menyebabkan bahwa DKI Jakarta, Jawa Barat, dan Jawa Timur, serta Banten adalah tempat terbesar dari penularan positif dari kasus Covid-19", jelas Menkeu.

Menkeu juga menambahkan bahwa pulau Jawa adalah pulau yang memberikan kontribusi sangat besar bagi perekonomian Indonesia. "Lebih 
dari 57\% ini nanti akan mempengaruhi cukup besar dari sisi prospek ekonomi dan kegiatan dari ekonomi masyarakat", tukas Menkeu dalam video conference APBN KITA April 2020. Kemudian, seiring adanya aturan terkait Work From Home (WFH) baik untuk sektor pemerintah maupun sektor swasta, maka mulai terjadi perlambatan kegiatan usaha di akhir bulan Maret 2020 yang berpotensi menurunkan penyerahan dalam negeri yang kemudian akan menekan penerimaan Pajak Pertambahan Nilai Dalam Negeri (PPN DN) di bulan April 2020.

Kondisi tersebut kemungkinan akan berlanjut dan semakin terkontraksi di bulan Mei, mengingat di bulan April sebagian daerah sudah melaksanakan Pembatasan Sosial Berskala Besar (PSBB) di beberapa wilayah terdampak. Sejalan dengan penerapan WFH dan PSBB tersebut, Pemerintah memberikan fasilitas perpajakan berupa relaksasi pembayaran $\mathrm{PPh}$ Pasal 29 OP dan pelaporan SPT $\mathrm{PPh}$ OP, yang mana berimbas pada belum optimalnya realisasi penerimaan $\mathrm{PPh}$ Pasal 29 OP.

Pandemi covid 19 sangatlah memberikan dampak yang besar khususnya di bidang perekonomian sehingga sector yang lainpun ikut terdampak seperti sector pendidikan. Di sekolah swasta khususnya di SMK Gazza Wiguna 1 untuk menghonor guru mengandalkan dari iuran SPP siswa. Namun, saat pandemic Covid 19 ini banyak siswa yang jarang bahkan sedikit membayar iuran SPP, ini dikarnakan ekonomi orangtua siswa terkena dampak dari pandemic Covid 19. Sehingga menurut bendahara SMK Gazza Wiguna 1 untuk system penghonoran saat pandemic ini mengandalkan uang iuran yang lain seperti iuran DSP, OSIS dan praktek dengan system berputar.

Dalam segi pelaporan atau penggunaan dana BOS menurut kepala SMK Gazza Wiguna 1 di masa pandemic Covid 19 ini mendapatkan kelonggaran tidak sama seperti saat normal . Dana BOS bisa digunakan untuk membeli kuota siswa yang tidak mampu membeli kuota dan untuk membeli peralatan kebersihan seperti sabun cuci tangan dan hand sanitizer. Kementerian Pendidikan dan Kebudayaan mengizinkan penggunaan dana Bantuan Operasional Sekolah (BOS) serta Bantuan Operasional Penyelenggaraan (BOP) PAUD dan Pendidikan Kesetaraan untuk mendukung kesiapan satuan pendidikan 
selama pandemi Covid-19. Menteri Pendidikan dan Kebudayaan (Mendikbud) Nadiem Makarim menjelaskan penggunaan dana BOS pada saat pandemi Covid-19 sesuai Permendikbud Nomor 19/2020 tentang Perubahan Petunjuk Teknis BOS dan Permendikbud Nomor 20/2020 tentang Perubahan Petunjuk Teknis BOP PAUD dan Kesetaraan di Masa Kedaruratan Covid-19. "Kami memberikan relaksasi penggunaan dana BOS hingga 100 persen pada saat pandemi Covid-19 ini," ujar Nadiem dalam webminar, Senin $(15 / 6 / 2020)$.

Nadiem menambahkan kelonggaran penggunaan dana BOS BOP hanya dapat digunakan untuk kegiatan dan pembelanjaan tertentu. Pertama untuk pembelian pulsa, paket data, dan/atau layanan pendidikan daring berbayar bagi pendidik dan/atau peserta didik dalam rangka pelaksanaan pembelajaran dari rumah. Kedua dana BOS serta BOP PAUD dan Kesetaraan dapat digunakan untuk pembelian cairan atau sabun pembersih tangan, pembasmi kuman, masker atau penunjang kebersihan dan kesehatan lainnya termasuk alat pengukur suhu tubuh tembak (thermogun). (Johannes, berita online Kompas.com, 2020).

\section{KESIMPULAN}

Proses perencanaan kebutuhan pembiayaan dilakukan dengan mengadakan rapat untuk menyusun RKAS (Rencana Kerja Anggaran Sekolah ) dibuat di awal tahun pelajaran dengan yayasan, kepala sekolah dan structural. Perencanaan meliputi kebutuhan sekolah dan kegiatan sekolah. Jika terdapat pengeluaran yang lebih besar dibandingkan pemasukan, maka biaya yang di anggarkan di RKAS akan diadakan pengurangan. Pada saat pelaksanaan dibutuhkan keahlian seorang kepala sekolah dalam memanaj anggaran tersebut. Disaat pandemic covid 19 seperti ini banyak program yang tertundah sehingga khususnya di semester genap tahun ajaran 2020/2021 banyak kegiatan yang tidak terlaksana. Di SMK Gazza Wiguna 1 pedoman pengelolaan untuk dana partisipasi dari masyarakat meliputi lingkup structural yayasan dan kepala sekolah. Jika dari dana BOS pedomannya dari Kemendikbud.

Di sekolah SMK Gazza Wiguna 1 dalam pelaksanaan pembiayaan jika terdapat ketidak seimbangan antara pemasukan dan pengeluaran maka anggaran untuk pengeluaran akan dikurangi biayanya. Disaat pandemic 
Covid 19 ini pelaksanaan pembiayaan focus untuk penghonoran guru dan peremajaan sekolah seperti mengecat ulang dan merawat gedung sekolah.

Prosedur pengawasan pembiayaan di SMK Gazza Wiguna 1 dari partisipasi masyarakat maka komite terlibat,untuk yayasan, sekolah harus tetap melaporkan hasil dari setiap kegiatan tersebut kepada yayasan sebagai bentuk pengawasan, jika untuk dana BOS pengawasannya harus di laporkan ke Provinsi dalam bentuk laporan online dan laporan fisik. Pelaporan pembiayaan SMK Gazza Wiguna 1 dalam bentuk pembukuan seperti buku kas umum dan kas tunai sebagai bukti. Untuk pembukuannya ada kartu SPP dan buku kas umum lalu di input ke computer untuk dijadikan laporan bulanan, laporan per 6 bulan dan laporan tahunan kepada sekolah dan yayasan.

Dampak dari pandemic Covid 19 terhadap SMK Gazza Wiguna 1 sangat jelas, iuran SPP tidak seperti biasanya sedangkan honor guru haru tetap di keluarkan setiap bulannya, ini menjadi sesuatu yang benar benar harus di pikirkan oleh kepala sekolah bahkan mungkin sampai harus meminjam uang karna untuk honor harus tetap dikeluarkan.

Di sekolah swasta khususnya di SMK Gazza Wiguna 1 untuk menghonor guru mengandalkan dari iuran SPP siswa. Namun, saat pandemic Covid 19 ini banyak siswa yang jarang bahkan sedikit membayar iuran SPP, ini dikarnakan ekonomi orangtua siswa terkena dampak dari pandemic Covid 19. Sehingga SMK Gazza Wiguna 1 untuk system penghonoran saat pandemic ini mengandalkan uang iuran yang lain seperti iuran DSP, OSIS dan praktek dengan system berputar.

Dalam segi pelaporan atau penggunaan dana BOS menurut kepala SMK Gazza Wiguna 1 di masa pandemic Covid 19 ini mendapatkan kelonggaran tidak sama seperti saat normal . Dana BOS bisa digunakan untuk membeli kuota siswa yang tidak mampu membeli kuota dan untuk membeli peralatan kebersihan seperti sabun cuci tangan dan hand sanitizer.

\section{DAFTAR PUSTAKA}

Abdullah, Thamrin. 2012. Pembiayaan Pendidikan, Perangkat Pembelajaran di Program Pascasarjana Universitas Negeri Jakarta. 
Abidin, Achmad Anwar, 'Manajemen Pembiayaan Pendidikan Tinggi Dalam Upaya Peningkatan Mutu (Studi Kasus Pada Perguruan Tinggi Swasta Menengah Di Surabaya)', Jurnal Penjaminan Mutu, 3 (2017), 8799<https://doi.org/10.25078/jpm .v3i1.95>

Ahmad, Munir.(2013). Manajemen Pembiayaan Pendidikan dalam Perspektif Islam, Vol. 8, No. 2, hal. 225

Arikunto, S. (2008). Manajemen Pendidikan,Yogyakarta: Aditya Media.

Ashadi.R.N \& Suhaeb S. (2020). Hubungan Pemanfaatan Google Classroom Dan Kemandirian Terhadap Hasil Belajar Mahasiswa Ptik Pada Masa Pandemi. Jurnal MEDIA ELEKTRIK, Vol. 17, No. 2 hal. 46

Azhari.L.U. \& Kurniady A.D. Manajemen Pembiayaan Pendidikan, Fasilitas Pembelajaran, Dan Mutu Sekolah. Jurnal Administrasi Pendidikan Vol.XXIII No.2 Tahun 2016 hal. 26

Budi,B. (2018). Manajemen Pembiayaan Pendidikan Pada Sekolah Dasar Yang Efektif. LIKHITAPRAJNA. Jurnal Ilmiah.Fakultas Keguruan dan Ilmu Pendidikan, Volume. 18, Nomor 1, hal 42-59.

Coombs, Philip. H. 1982. Apakah Perencanaan Pendidikan Itu (terj), Bhatara Karya Akasara, Jakarta.
Dedy, A.K., Linda, S., \& Siti, N.(2018). Manajemen Pembiayaan Pendidikan Tehadap Mutu Sekolah Menengah Kejuruan Jurnal Penelitian Pendidikan, hal 264

Dedy,A.K. (2011). Pengelolaan Pembiayaan Sekolah Dasar Di Kabupaten Bandung,Jurnal Penelitian Pendidikan, Vol. 12 No. 1

Depdiknas. Peraturan Pemerintah (PP) No.19 tahun 2005 dan PP No.48 tahun 2008

Dwi Atmanti, Hastarini, 'Investasi Sumber Daya Manusia Melalui Pendidikan', Jurnal Dinamika Pembangunan, 2 (2005), 30-39 <http://eprints.undip.ac.id/16864 $>$

Fattah, N. 2002. Ekonomi dan Pembiayaan Pendidikan. Bandung. PT. Remaja Rosdakarya

Fattah, N. 2008. Pembiayaan Pendidikan: Landasan Teori dan Studi Empiris. Jurnal Pendidikan Dasar, 9.

Ferdi, W.P.(2013). Pembiayaan Pendidikan: Suatu Kajian Teoritis .Jurnal Pendidikan dan Kebudayaan, Vol. 19, Nomor 4, hal 567.

Herujito, Yayat, Dasar-Dasar Manajemen, Bogor: PT Grasindo, 2011

Hoy,W.K.,\&Miskel,C.G.(2008). Education Administration; Theory. Research, and Practice. New York: McGraw-Hill Csmpions. 
Johanes,M.(2020,Juni 15). Kompas.com (https://www.kompas.tv/article/8 7144/ini-petunjuk-mendikbudnadiem-soal-penggunaan-danabos-bop-paud-selama-pandemicovid-19)

Kurniady dkk. 2016. Manajemen Pembiayaan Pendidikan Terhadap Mutu Sekolah Menengah Kejuruan. Jurnal Penelitian Pendidikan UPI

Matin, 2014. Manajemen Pembiayaan Pendidikan: Konsep dan Aplikasinya. Jakarta : Rajawali Pers

Morphet Edgar C. 1983. The Economic \& Financing of Educatiort. New Jersey: Prentice Hall. Inc. Engetwood Cliffs

Munir A.. Manajemen Pembiayaan Pendidikan dalam Perspektif Islam. Jurnal UIN Maulana Malik Ibrahim Malang, Vol. 8, No. 2, Desember 2013
Nur, G.(2019). Implementasi Manajemen Pembiayaan Pendidikan. Jurnal Manajemen Pendidikan Islam, Volume 7, Nomor 1

Oktiani, E. (2020, Mei 13). Sindonews.com (https://ekbis.sindonews.com/rea d/26405/34/akibat-wabahcorona-40-sektor-ini-terdampakparah-1589306757)

Risnandi A. \& Prayoga A. Manajemen Pembiayaan Pendidikandi Madrasah Aliyah Darussalam Sumedang. Ejournal, Cakrawla: Studi Manajemen Pendidikan Islam Dan Studi Sosial Vol. 3 No.2. 2019
Rizal, F. (2020, Juli 8). Halodoc.com (https://www.halodoc.com/keseh atan/coronavirus)

Rusdiana, A., Manajemen Operasi, ed. by Beni Ahmad Saebani, Edisi 1 (Bandung: CV Pustaka Setia, 2014)

Rusdiana, A., Manajemen Pembiayaan Pendidikan, II (Bandung: LP2M UIN Sunan Gunung Djati Bandung, 2017)

Sagala, Syaiful. 2011. Manajemen Strategik Dalam Peningkatan Mutu Pendidikan. Bandung : Alfabeta

Setiowati E. N. (2007). Manajemen Pembiayaan Pendidikan Pondok Pesantren dan Lembaga Pendidikan Terpadu Nurushiddiiq Cirebon, hal 170

Taufik, .Ayuningtyas.E.A. (2020). Dampak Pandemi Covid-19 Terhadap Bisnis Dan Eksistensi Platform Online. Jurnal Pengembangan Wiraswasta, Vol. $22 \quad$ No. 01,hal. 22. http://ejurnal.stieipwija.ac.id/ind ex.php/jpw

Teguh Santoso, Mitigasi Dampak Ekonomi Virus Corona, Diambil dari https://news.detik.com/kolom/d4913486/mitigasi-dampakekonomivirus-corona, diakses pada tanggal 24 Agustus 2020 